\title{
Arena of Islamic Identity Battles in Films by Nurman Hakim
}

\author{
Muh. Bahruddin \\ Communication Sciences Department \\ Universitas Indonesia \\ Jakarta \\ muh.bahruddin77@gmail.com
}

\author{
Eriyanto \\ Communications Sciences Department \\ Universitas Indonesia \\ Jakarta \\ Eriyanto2001@gmail.com
}

\begin{abstract}
This study aims at disclosing the practices of Islam in Indonesia framed in the films by Nurman Hakim, among them are 3 Doa 3 Cinta (3 Prayers 3 Love) (2008), Khalifah (2011), and Bid'ah Cinta (2017). These three films portray the religious reality of Islamic society in post-reform Indonesia. The permeation of transnational Islamic practices, especially those adopted from the Middle East, is believed to have the potential to become a radical Islam and threaten the existence of a cultural Islam that promotes tolerance and appreciates the existence of Indonesian culture. Through the production of Islamic-themed films, Nurman Hakim believes that film is a representation of society and its era. Therefore, the film depicts socio-political, cultural, ideological, and religious circumstances in society. This is where a filmmaker has a very important role in producing the film. In his conscious and subconscious mind, a filmmaker will bring out all that has been absorbed from his surroundings. The audience can read the religious views of a filmmaker through the created film products. Using the perspectives of cultural studies and critical multiculturalism, this study perceives that the creation of Nurman Hakim films is not only to maintain inclusive cultural Islam but also to ward off the exclusive and scriptural radical Islam in understanding the holy verses of the Qur'an and hadith. Nurman Hakim's films also become the antithesis of mainstream Islamic-themed films that referred to the success of the Ayat-Ayat Cinta of Love movie which had adopted Middle Eastern Islamic identity.
\end{abstract} studies

Keywords-film; Nurman Hakim; Islamic identity; cultural

\section{INTRODUCTION}

Film is a medium that describes socio-political, cultural, ideological, and religious circumstances in society. This is where a filmmaker has a very important role in producing the film. In his conscious and subconscious mind, a filmmaker will represent all that has been absorbed from his surroundings. The audience can read the religious views of filmmakers through the created film products [1].

Three films by Nurman Hakim titled 3 Doa 3 Cinta (3 Prayers 3 Love) (2008), Khalifah (2011), and Bid'ah Cinta (2017) are movies that have an Islamic theme among many other Islamic themes produced by the Indonesian film industries after 1998. The film potrays Islam for different side wide other Islamic-themed films that are widely produced in Indonesia.

Nurman Hakim's films always put two different ideas in them. One side of him interpreted Islam substantially that has long grown in the culture and society of Indonesia, on the other hand he also depicted a scriptually Islamic understanding that is considered threatening Indonesian Islamic society.

The movie 3 Doa 3 Cinta (3 Prayers 3 Love) (2008) represents radical Islam on the character of Syahid. He is a young man born from a poor family. Syahid is one of the santri (students) in a pesantren (islamic boarding school) institution. He was friends with two other friends who both have complicated issues in their family. Two friends of Syahid are Huda (Nicholas Saputra) and Ryan (Yoga Pratama). Huda had not seen her mother for a long time, who turned out to be a comforting lady. When the address found, it turns out his mother had died. Ryan must accept the fact that her mother will marry again. After getting a handycam gift from his mother, Ryan increasingly obsessed to continue his father's business, especially after seeing the night market troupe that played traditional movie drive-in in a village. Syahid (Yoga Bagus) himself is a poor santri who wanted to make money to be able to take his father to a hospital that has good quality. However, the money from his sold land was not sufficient for his father's expenses at the hospital. It was at this time that he met a man who claimed to be a religious figure with a scriptural understanding of Islam. Terror is a form of jihad that is believed to lead Muslims to heaven.

The movie Khalifah (2011) tells of a woman named Khalifah (Marsha Timothy) who was married to a young man named Rasyid (Indra Herlambang). She wanted to help her family who had difficulty with living expenses and was forced to marry Rasyid. But it turned out that Rasyid was a follower of hardline Islamic teachings. Her appearance began to change drastically. She wore a veil to obey her husband. Everyone views her cynically as a terrorist wife.

The film Bid'ah Cinta (2017) tells the love story of Kamal (Dimas Aditya) who was in love with Khalida (Ayushita). However, both had different Islamic understandings. Kamal had an Islamic understanding under the guidance of his uncle from the Middle East. While Ayushita grew up with a family 
that upholds the local culture, a substantially cultural-based Islam. In his journey, Kamal and his family even had to face Ayushita family as a result of Kamal's uncle trying to radically change society's understanding. The film ended with a suicide bombing from a place in Jakarta. One friend of Kamal's uncle is the suspect.

The three films by Nurman Hakim portray the reality of society that is considered a dangerous signal so that the government or the public should be aware. A hardline Islamic understanding is regarded as a threat of intolerance, even to fellow Muslims themselves who have different understandings.

Research on the film by Nurman Hakim was once conducted by Siti Hardiyanti [2] with the title Stereotyped Muslim Women in the Film Khalifah (Semiotic Analysis Roland Barthes). This research uses Barthes's semiotic approach in analyzing the content of Khalifah film. The focus in this study is on the image of Muslim women in society. Muslim women are regarded as second class in society. This is evident in the symbols used in the Khalifah film such as washing, cooking, fixing household furniture, and even making a living. However, a woman is required to be obedient to her father and her husband so that she is unable to make a decision for her own good. Hardiyanti also found that the female figure was shown as a dandy and flirting woman. This is seen in the female character, a veiled woman who became a salon customer of Kalifah. She always performed beauty treatments by being escorted by her husband. Almost all Khalifah customers were women. They wanted to show their beauty in front of men, especially to their partner.

In her research, Hardiyanti saw that the stereotype formed in the community, especially in Muslim women. It occurs due to the process of denotation and connotation. Hardiyanti took movie scenes and analyzed one by one by using Barthes's semiotic method that proposed the concept of denotation, connotation, and myth. The denotation process produces meaning explicitly and conclusively by referring to the reality of society, simultaneously produces connotation meaning, ie explicit and uncertain meaning so as to enable the birth of new interpretations. While myth is the development of connotation. The long-established connotation process in this society is then called myth.

Makbul Mubarak’s research [3] entitled Social Muslim in Nurman Hakim Movie emphasizes on film genre. Two films by Nurman Hakim titled 3 Doa 3 Cinta (3 Prayers 3 Love) and Khalifah are judged as two films that are social. These two films are two rare films that put forward the post-reform social scene. According to Mubarak, post-reform films tend to be individualistic, that is, by highlighting personal issues in view of religion as a solution. However, Nurman Hakim in the two films worked on to put religion as a living guide to solve social problems.

For Mubarak, religious-themed films for social solutions are like movies in the New Order era, especially Rhoma Irama movies. After reformation, however, Mubarak sees that many Islamic-themed films are directed to individual issues such as Ayat-Ayat Cinta, Cinta Bertasbih, and so on. Mubarak uses the case study method for researching two films by Nurman Hakim titled 3 Prayers 3 Love and Khalifah. Mubarak considered Nurman Hakim a pure film producer of postreform film. The film is considered as an Islamic-themed film that captures social portraits honestly, such as accommodating the other. For example, the existence of LGBT (lesbian, gay, bisexual, and transsexual) and dangdut singers who are vulgar in appearance.

Another study related to film and multicultural approach is the research of Dwi Retno Wahyuningtyas [4] under the title of Multicultural Identity Representation in the film Bride and Prejudice.

This research reveals a multicultural identity through race, class, gender, and ethnicity that is represented in the film Bride and Prejudice. This diversity arises on the basis of stereotypes and prejudices against two different cultures. On the subject of race, the study found that the film Bride and Prejudice laid the white race of America as an upscale race. While the brown skin tends to the South Asian (Indian) and middle class. This seterotype is considered to have grown in the society.

About the gender, this study found that the Bride and Prejudice film puts women not fully in male power. This is apparent in many ways which give them the opportunity to fulfill their wishes. Nevertheless, this does not mean that men (husbands/fathers) are no longer decision makers.

Wahyuningtyas sees that the Bride and Prejudice film had featured radical mutliculturalism, as Sumiko Higashi has defined, a commitment to restructure power relations among cultural communities. For example, the relationship of men with Indian women. So far Bollywood films have tended to put a woman as a figure who is in the power of men so that she has no chance to carry out her desire and obsession. But the Bride and Prejudice film is able to remodel the paradigm radically by giving women the opportunity to give freedom in reaching their dreams, even though they do not give up the male role as a decision maker.

\section{Methodology}

This study uses case study method with the perspective of cultural studies and critical multiculturalism. In-depth interviews were conducted with Nurman Hakim as the filmmaker. The researcher also made observations on the artifacts or works of 3 Doa 3 Cinta (3 Prayers 3 Love), Khalifah, and Bid'ah Cinta. These three films are Islamic-themed films with substantial insights based on cultural and community contexts. In the story, these three films laid substantial Islam against the understanding of scriptural Islam that is considered threatening peace in Indonesia. In addition, these three films also allude to the acts of terrorism that are believed to be part of a scriptural Islam. An understanding that sees religious verses literally or textually.

Fiske mentions that cultural studies consider culture something political because it contains the arena of conflict and contestation. It is seen as a key to the production and reproduction of social relations in everyday life [5, p. 150]. In the media (film), the approach of cultural studies is based on 
the freedom of society (sineas) in defining the identity of religion (Islam) in society so that it gives birth to various meanings in the film.

Douglas Kellner [6, pp. 27-28] mentions many models of cultural studies such as the neo-Marxist model developed by Lukàcs, Gramsci, Bloch, and Frankfurt School, feminist, to psychoanalytic. But in Britain and the United States, the main traditions of cultural studies combine a number of theories such as social theory, culture, history, philosophy, and certain politics so as to overcome academic problems with the specialization of splitting the fields of media, culture, and communication studies. Meanwhile, cultural studies are applied by using transdisciplinary conceptions that refer to social, economic, political, historical, communication, literary, and cultural theory, philosophy, and other theoretical discourses.

For Kellner, this approach goes beyond the boundaries between the various academic disciplines. In particular, one should not stop at the border of the text, but must see how it conforms to the textual production system, and how the texts are part of the genre or type of production and have intertextual construction. Thus, a transdisciplinary approach involves cross-disciplinary crossing from text to context, and thus from text to culture and society. Cultural studies, therefore, draw on different fields with the complexity of the theory and the contradictions of the effects of various forms of media / culture / communication in our lives and not only show how these artifacts function as instruments of domination, but also offer resources for resistance and change.

According to Kellner [6, p. 95], to develop a critical point of view requires one to convey the social constitution of the concepts of gender, class, race, ethnicity, and sexuality, and how the representation of this phenomenon raises an identity in contemporary society, and how alternative representations generate new and different identities. Maintaining a critical point of view also requires the interpretation of culture and society in power relations, dominance, and tenacity, and expresses various forms of oppression in a society through a multicultural perspective.

\section{DISCUSSION}

\section{A. The Consequence of Democracy and Globalization}

The consequence of geographical conditions in Indonesia is the birth of many cultures. Every culture has a way of interpreting and signifying what they believe. One of the beliefs is the identity of religion (Islam). The freedom of post1998 democracy has a major role in respecting the opinions of subordinate groups, which had been silenced by the New Order regime for some 32 years. On the other hand, global penetration grew rapidly as freedom gained by Indonesians. Everything related to lifestyle, ideology, or global identity goes to Indonesia very easily, especially through the media.

Azyumardi Azra [7, pp. 171-172] writes that the diversity of thought in Islam is a logical consequence of the growth and development of Islam. This cannot be separated from the geographical facts in understanding and explaining Islam in
Indonesia. The position of the archipelago away from Arabia causes the understanding of Islam in Indonesia is different from other regions, especially in the Middle East, North Africa, and South Asia [8, p. 18].

From the film's point of view, Eric Sasono [9, p. 60] sees this condition as a close relationship between Islam and popular culture. That is, regardless of the real commercial dimension, film as a medium is used to disseminate the broad spectrum of Islam by various groups of Muslims.

Globalization went into Indonesia in the early 1980s. This is marked by the number of Hollywood movies that controled theaters in Indonesia. The penetration of global culture is also marked by the emergence of other audio-visual media such as video, cassette, laser disc, VCD, and DVD in 1980-1990 [10, p. 127].

This fact is captured by the Muslim society as the right moment to combine local culture and global culture (cultural acculturation). Yuswohadi et al [11, p. 114] mentions that the era of the 1990s was a period of Hijab revolution 1.0 and the early 2010s was called the period of Hijab revolution 2.0. The trigger of the hijab revolution 1.0 was the allowance of the use of hijab in schools by the New Order government. This has led to widespread use of freedom of expression in society. The Muslim society is no longer afraid to express their religious teachings in the form of covering aurat (private parts of the body) as taught by their beliefs.

Both of these conditions resulted in a resurgence of identity in the reform era interpreted as a freedom in bringing local (regional) identity and new political awareness to revive the values of local wisdom on the basis of primordial religion on the one hand.

On the other hand, there is an effort to adopt outside understanding to be projected as a new identity, especially in understanding religion. This is what gave birth to a diverse Islamic identity with different religious practices, especially in the culture of movies.

The filmmaker (director, producer, and writer) Nurman Hakim portrays the diversity of Islamic identity in 3 films, 3 Doa 3 Cinta (3 Prayers 3 Love), Khalifah, and Bid'ah Cinta. But this diversity is actually considered to threaten the state, especially in disseminating the new Islamic identity. These three films are at once considered the antithesis of Islamicthemed films which, according to Nurman Hakim, are the seeds of Islamic radicalism in Indonesia.

\section{B. Arena of Islamic Identity Battles in Three Films by Nurman Hakim}

Different from the previous studies on Nurman Hakim films that focus more on gender issues and interpret Islam as a social solution, in the film titled Khalifah, Hardiyanti's research highlights the social status of Muslim women who are brought out as subordinates of men. They are the second class in society. Hardiyanti also sees the figure of a woman who is shown as a dandy and lure woman.

Makbul Mubarak's research on the movie 3 Doa 3 Cinta (3 Prayers 3 Love) and Khalifah highlights about the social style of Islamic-themed films in post-reformation. According to Mubarak, post-reform films tend to be individualistic, that is, 
by highlighting personal issues in view of religion as a solution. In contrast, Nurman Hakim worked on the two films by putting religion as a living guide to solve social problems. Both of these studies do not at all mention how Nurman Hakim narrated an Islamic group that is considered harmful to society. Especially in understanding Islamic teachings that are considered radical.

This is what is interesting for the researcher to examine the problem. The researcher looks at how Nurman Hakim struggled to counter the scriptual understanding of Islam which is rapidly growing in Indonesia. This understanding of Islam, in Nurman Hakim's opinion, is a seed of radicalism in the body of Islam in Indonesia.

In the movie 3 Prayers 3 Love, Nurman Hakim uses the character of Syahid as one of the students in the boarding school which has been influenced by an ustadz (a teacher), who carries the mission of radical understanding of Islam. Such understanding uses the lure of heaven by means of jihad (fighting in the way of God). Jihad is carried out in violent ways such as committing suicide bombing in the midst of a society that is considered to be a kafir. This is what Nurman Hakim considers to threaten peace in Indonesia. Nurman Hakim sees that Islamic radical understanding of Indonesia is campaigned through pengajian (recitation forum). Syahid is a film character who is described as having been exposed through ustadz (religious teacher) through recitation forum in a mushollah (a prayer-house) in a village.

On the other hand, Nurman Hakim also perceives that the problem of poverty, disharmony in the family, and a number of other problems are believed to be a factor that can make a person easily influenced by the promises of heaven in the name of jihad.

Likewise, it is depicted in the movie Khalifah by using the main character named Khalifah. Women from poor families must be willing to be the wives of a young man who has a scripturally religious understanding that has the potential to become a radical Islam. Khalifah family is a poor family so her father uses her as a sacrifice to redeem his debts to a man by way of surrendering her to marry. She was willing to marry a man whom she was not in love with. Even as a wife, she must submit to her husband in interpreting Islam differently. In the course of her domestic life, she must wear a veil to obey his husband's command. Consequently, she was forced to accept public scorn and condemnation as a terrorist wife.

In the film Bid'ah Cinta, Nurman Hakim has been fighting against radical Islam through the character of Khalida whose family has a strong enough understanding of religion. Khalida's father was a kiai (a teacher) in his village. Khalida established a love with a young man named Kamal. He comes from a family with different understanding of Islam, especially since the arrival of Kamal's uncle from the Middle East. All the mosque administrators in the village were taken over by his group. Cultural customs such as memorials of the maulid nabi (commemorating the birthday of Prophet Muhammad) and jamiah diba' (a recitation forum to praise Prophet Muhammad) in the village began to be removed. These activities are considered bid'ah (a worship that was never done by the Prophet Muhammad). Some people began to be influenced by Kamal's uncle and his group's teachings. However, in this film, Nurman Hakim thwarted their efforts through the character of Khalida and his family in a peaceful way so that people return to previous Islamic understanding. In the movie Khalifah, Nurman Hakim still uses the background of terrorism. This is seen in the scene of one of the members of radical Islamic group that is indicated as a terrorism suspect in a bombing in Jakarta.

Three films by Nurman Hakim 3 Doa 3 Cinta (3 Prayers 3 Love), Khalifah, and Bid'ah Cinta are movies created to counter the radical understanding of Islam that is considered to be the seeds of terrorism in Indonesia

\section{CONCLUSION}

Nurman Hakim is a director, producer, and screenwriter of Islamic-themed films that are consistent in interpreting Islam substantially. For him, a substantial understanding of Islam that has long grown in Indonesia must be preserved. The text of religion and the context of society are two things that cannot be separated in interpreting the teachings of Islam. On the other hand, he also fights against Islamic groups who have a scriptural understanding and potentially become a radical understanding. Terrorist acts in Indonesia are believed to be part of a scriptual understanding of Islam. The perspectives of cultural studies and critical multiculturalism are relevant approaches used to reveal diverse identities in society. Moreover, critical multiculturalism is relevant to be used to see filmmakers fighting against groups that are considered to dominate and threaten freedom and peace in society through their artifacts or works.

\section{ACKNOWLEDGMENT}

I would like to thank my wife and children for their understanding and patience. I would also like to thank the Indonesia's Leading Lecturer Scholarship (BUDI-DN) LPDP, Universitas Indonesia, and Institut Bisnis dan Informatika Stikom Surabaya for their support my academics. Finally, I would like to thank Nurman Hakim who has been cooperative to be an informant during my research.

\section{REFERENCES}

[1] N. Hakim, "Perang Ide dan Film Religi [Idea War and Religious Movies],” Tempo Online, September 28, 2017. [Online]. Available: https://indonesiana.tempo.co.

[2] S. Hardiyanti, Stereotip Wanita Muslimah dalam Film Khalifah: Analisis Semiotik Roland Barthes [Muslim Women Stereotypes in the Movie of Khalifah: Roland Barthes Semiotic Analysis]. 2017.

[3] M. Mubarak, "Muslim Sosial dalam Dua Film Nurman Hakim [Social Muslims in Two Movies of Nurman Hakim],” in Ultimart. vol. 5, no. 1, pp 31-48, March 2013.

[4] D.R. Wahyningtias, "Representasi Identitas Multikultural dalam Film Bride dan Prejudice [Multicultural Identity Representation in the Movie 'Bride and Prejudice]," Unpublished Master's Thesis, Surabaya: Airlangga University, 2007.

[5] J. Fiske, Memahami Budaya Populer (Terjemahan) [Understanding Popular Culture (Translated)]. Yogyakarta: Jalasutra, 2011.

[6] D. Kellner, Media Culture: Cultural Studies, Identity and Politics between the Modern and the Postmodern. London and New York: Routledge, 2003. 
[7] A. Azra, "Jaringan Islam Nusantara (Islam Nusantara Network)”, in Islam Nusantara dari Ushul Fiqh hingga Paham Kebangsaan [Islam Nusantara from Ushul Fiqh to Nationalism], A. Sahal (Eds.). Bandung: Mizan, 2015.

[8] A. Azra, Islam Nusantara Jaringan Global dan Lokal [Global and Local Branch of Islam Nusantara]. Bandung: Mizan, 2002.

[9] E. Sasono, "Islamic Themed-Films in Contemporary Indonesia: Commodified Religion or Islamization?” in Asean Cinema, Fall/Winter, pp. 48-68, 2010.
[10] A. Armando, Televisi di Indonesia di Bawah Kapitalisme Global [Indonesian Television under Global Capitalism]. Jakarta: Penerbit Buku Kompas, 2016.

[11] Yuswohady, I.A. Herdiansyah, F. Fatahilah, and H. Ali, Gen M: Generation Muslim. Yogyakarta: Penerbit Bentang, 2017. 